Nova Southeastern University

Florida

NOVA SOUTHEASTERN

UNIVERSITY

NSUWorks

Marine \& Environmental Sciences Faculty Articles Department of Marine and Environmental Sciences

$2-1-2017$

\title{
Primary Utricle Structure of Six Halimeda Species and Potential Relevance for Ocean Acidification Tolerance
}

Katherine E. Peach

Florida Atlantic University; Broward College

Marguerite S. Koch

Florida Atlantic University

Patricia Blackwelder

University of Miami; Nova Southeastern University, pblackwe@nova.edu

Debbie Guerrero-Given

Max Planck Florida Institute for Neuroscience

Naomi Kamasawa

Max Planck Florida Institute for Neuroscience

Find out more information about Nova Southeastern University and the Halmos College of Natural Sciences and Oceanography.

Follow this and additional works at: https://nsuworks.nova.edu/occ_facarticles

Part of the Marine Biology Commons, and the Oceanography and Atmospheric Sciences and Meteorology Commons

\section{NSUWorks Citation}

Katherine E. Peach, Marguerite S. Koch, Patricia Blackwelder, Debbie Guerrero-Given, and Naomi Kamasawa. 2017. Primary Utricle Structure of Six Halimeda Species and Potential Relevance for Ocean Acidification Tolerance .Botanica Marina , (1) : 1 -11.

https://nsuworks.nova.edu/occ_facarticles/789.

This Article is brought to you for free and open access by the Department of Marine and Environmental Sciences at NSUWorks. It has been accepted for inclusion in Marine \& Environmental Sciences Faculty Articles by an authorized administrator of NSUWorks. For more information, please contact nsuworks@nova.edu. 
Katherine E. Peach*, Marguerite S. Koch, Patricia L. Blackwelder,

Debbie Guerrero-Given and Naomi Kamasawa

\section{Primary utricle structure of six Halimeda species and potential relevance for ocean acidification tolerance}

DOI 10.1515/bot-2016-0055

Received 16 June, 2016; accepted 23 November, 2016; online first 12 January, 2017

\begin{abstract}
Variations in utricle morphology may be responsible for different tolerances to ocean acidification (OA) within the macroalgal genus Halimeda, an important sediment producer on reefs. However, differences in species' utricle morphology and their relationship to calcification and crystal formation have not been well articulated. In the present study, we characterized the utricle morphologies of six Halimeda species. Primary utricle ultrastructure was quantitatively and qualitatively compared to tissue inorganic content and crystal microstructure. Morphologies differed across species and several morphometric relationships were revealed. Primary utricle size $\left(r^{2}=0.70\right)$ and diffusion pathway length $\left(r^{2}=0.87\right)$ had inverse relationships with inorganic content based on regression analyses, and corresponded to crystal microstructure form. Species with large utricles and long diffusion pathways contained more narrow $(\sim 0.15 \mu \mathrm{m})$ aragonite needles and minimal micro-anhedral crystal formations. In contrast, species with small utricles and short diffusion pathways elucidated aggregates of micro-anhedral crystals and wider aragonite needles $(\sim 0.30 \mu \mathrm{m})$. Species' utricle characteristics generally corresponded to specific evolutionary lineages. Thus, characteristics of Halimeda utricle morphology may control long-term adaptive responses to $\mathrm{OA}$, an idea articulated in the broader literature.
\end{abstract}

*Corresponding author: Katherine E. Peach, Biological Sciences Department, Aquatic Plant Ecology Lab, Florida Atlantic University, 777 Glades Rd, Boca Raton, FL 33431, USA; and Science and Wellness Department, Broward College South Campus, 7200 Pines Blvd, Pembroke Pines, FL 33024, USA, e-mail: peach.kate@comcast.net Marguerite S. Koch: Biological Sciences Department, Aquatic Plant Ecology Lab, Florida Atlantic University, 777 Glades Rd, Boca Raton, FL 33431, USA

Patricia L. Blackwelder: University of Miami, Center for Advanced Microscopy, 1252 Memorial Drive, Coral Gables, FL 33146, USA; and Nova Southeastern University, 8000 North Ocean Drive,

Dania Beach, FL 33004, USA

Debbie Guerrero-Given and Naomi Kamasawa: Max Planck Florida Institute for Neuroscience, Electron Microscopy Facility, One Max Planck Way, Jupiter, FL 33458, USA
Keywords: aragonite; diffusion pathway; Halimeda; microstructure; ultrastructure.

\section{Introduction}

Filament morphology has been proposed to be a factor contributing to species-specific responses within the tropical calcifying macroalgal genus Halimeda to ocean acidification (OA) (Price et al. 2011, Comeau et al. 2013, Campbell et al. 2014, 2015, Meyer et al. 2015). Halimeda thalli are composed of coenocytic (multi-nucleate) filaments that swell at their termini, resulting in the adherence of filament tips (Figure 1). The fusion of the outermost filaments or primary utricles creates compartments just anterior of the primary utricles called primary inter-utricle spaces. Because of the fusion of the primary utricles, the primary inter-utricle spaces become physically isolated from external seawater. It is within these inter-utricle spaces that calcium carbonate $\left(\mathrm{CaCO}_{3}\right)$ precipitates, primarily in the form of dense aragonite crystals (Hillis-Colinvaux 1980). Thus, the potential for precipitation of aragonite crystals and their susceptibility to dissolution under future OA conditions may be influenced by the size, orientation, and degree of lateral adhesion between adjacent primary utricles. Species-specific differences in morphology of primary utricles and their adhesion likely influences the diffusion pathways and thereby uptake of ions (e.g. $\mathrm{Ca}^{2+}, \mathrm{CO}_{3}{ }^{2-}$ ) necessary for $\mathrm{CaCO}_{3}$ precipitation (Borowitzka and Larkum 1976, Böhm et al. 1978). Further, diffusion pathways between primary utricles control $\mathrm{H}^{+}$fluxes, either from the bulk seawater into the primary inter-utricle spaces or removal from the primary inter-utricle spaces to prevent accumulation of $\mathrm{H}^{+}$, a product of calcification. This removal of $\mathrm{H}^{+}$from primary inter-utricle spaces would be across a shallower concentration gradient under OA, and if an active process is needed. This would correspond to a greater energetic cost to the algae leading to lower calcification rates, as in corals (Jokiel 2011, Ries 2011, Cyronak et al. 2015).

We examined morphologies of six Halimeda species to ascertain the role thalli morphology may have on 


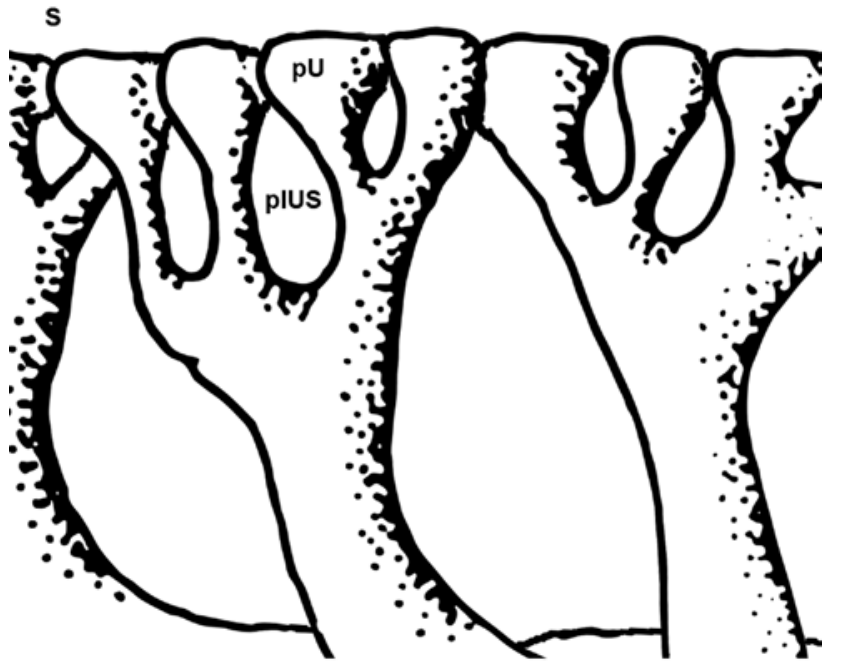

Figure 1: Illustration of a vertical section of a Halimeda copiosa segment showing basic architecture of the outermost filaments. Note how the swollen outer filaments or primary utricles $(\mathrm{pU})$ adhere, creating a physical barrier between primary inter-utricle spaces (pIUS) and external seawater (S). Artwork credit: Chris Johnson.

susceptibility to OA in this genus. Specifically, we measured primary utricle sizes and lengths of diffusion pathways and examined how these morphological characteristics were related to tissue mineral content and crystal microstructure within primary inter-utricle spaces. Crystal microstructure investigations focused on the dimensions of aragonite needles in primary inter-utricle spaces, and micro-anhedral crystal formations at the boundary where the primary utricle meets the primary inter-utricle space. Primary utricle size and diffusion pathway length were compared across species using transmission electron microscopy (TEM) and crystal microstructure was identified by scanning electron microscopy (SEM).

\section{Materials and methods}

\section{Species and sampling locations}

A total of 120 thalli of six Halimeda species (Figure 2) were collected off the northern coast of Little Cayman Island (August 2014) from three reef habitats where each species occurs in high densities (Figure 3, Table 1). Halimeda incrassata was collected from the shallow back reef lagoon, $H$. tuna and $H$. monile were harvested from the spur and groove reef system, $H$. opuntia was collected on the seaward edge of a sand groove at the fore reef ledge, and $H$. copiosa and H. goreauii were harvested from under the ledge in deep shade. Specimens were transported in

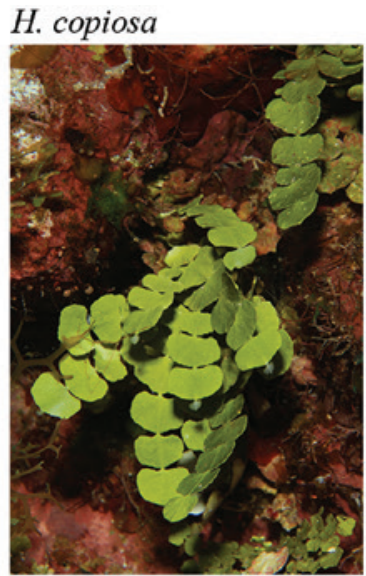

H. goreauii

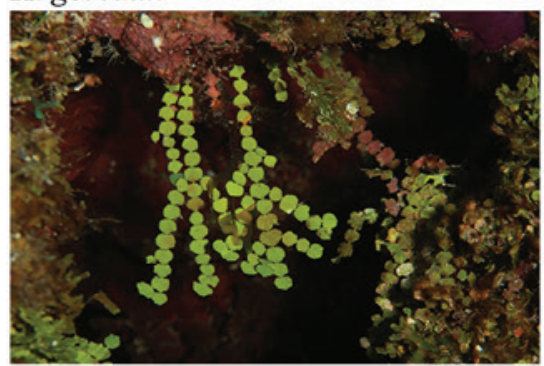

H. monile

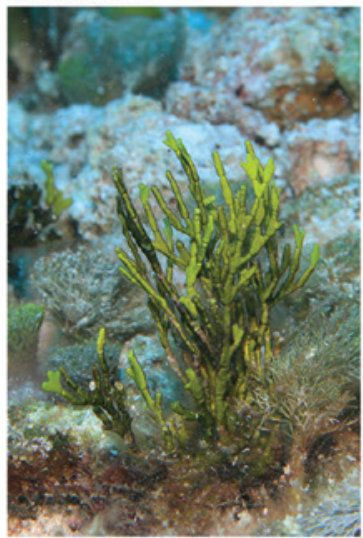

H. opuntia

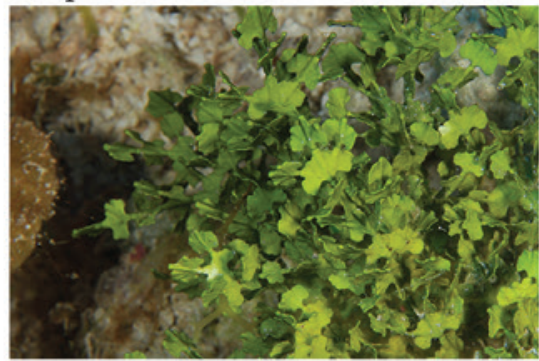

H. incrassata

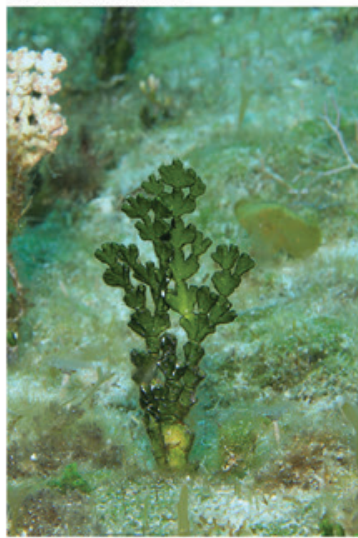

H. tuna

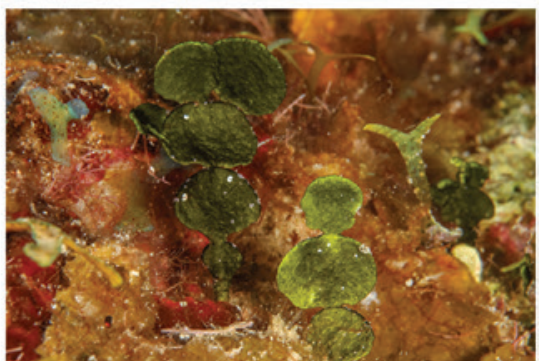

Figure 2: Photographs of the six Halimeda species examined at their natural growth sites. 


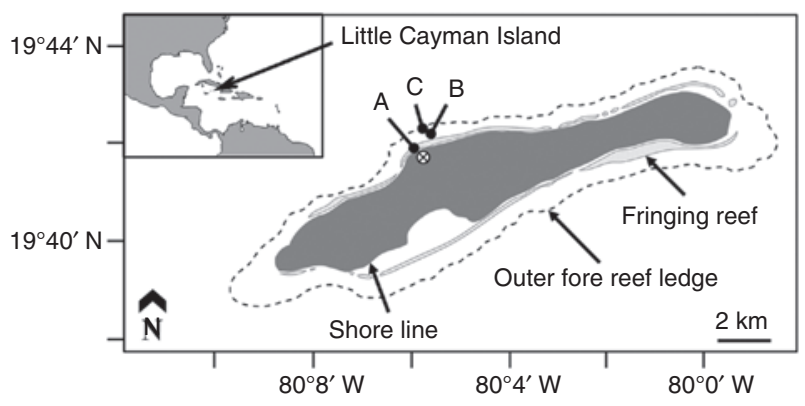

Figure 3: Location of the collection sites and Little Cayman Research Center (LCRC) shown as encircled multi symbol on the northern coast of Little Cayman Island in the Caribbean (inset). The three collection sites were: $(A)$ a shallow $(<2 \mathrm{~m})$ back-reef lagoon $\sim 250 \mathrm{~m}$ from LCRC, (B) a spur and groove fore-reef $(\sim 15 \mathrm{~m})$ $\sim 700 \mathrm{~m}$ northeast of LCRC and (C) an outer fore-reef ledge $(\sim 18 \mathrm{~m})$ $\sim 900 \mathrm{~m}$ northeast of LCRC.

seawater from the collection sites to the Little Cayman Research Center (LCRC) where they were immediately prepared for TEM and SEM analyses (described below). Species identification was accomplished using microscopy and keys by Hillis-Colinvaux (1980) and Littler and Littler (2000).

\section{TEM sample preparation and microscopy}

Apical segments of freshly harvested thalli were immediately fixed in $2 \%$ glutaraldehyde in $0.05 \mathrm{M}$ cacodylate-buffered seawater (Electron Microscopy Sciences, Hatfield, PA,
USA) and stored at $4^{\circ} \mathrm{C}$. Fixed segments were halved along the vertical midline, post-fixed in $1 \% \mathrm{OsO}_{4}$ buffer (Electron Microscopy Sciences, Hatfield, PA, USA), and dehydrated through a series of graded ethanol concentrations $(20 \%-$ $100 \%)$. One half of each segment was embedded in Spurr resin and the remaining half was reserved for SEM analysis (see below). Thin sections $(80 \mathrm{~nm})$ were cut of resinembedded samples (Leica EM UC7 Ultramicrotome, Leica Microsystems Inc., Buffalo Grove, IL, USA) and stained with 3\% uranyl acetate (3 $\mathrm{min}$ ) followed by lead citrate (1 min). Stained sections were examined with a TEM (FEI Tecnai G2 Spirit BioTWIN, Thermo Fisher Scientific Inc., Hillsboro, OR, USA) at $100 \mathrm{kV}$. Our observations and measurements focused on morphological characteristics of the primary region of segments consisting of primary utricles (pU) and primary inter-utricle spaces (pIUS; Figure 4). In the primary region of one representative sample from each species, measurements $(\geq 7)$ of diffusion pathway lengths between adhered primary utricles and their surface diameters were made using image processing software (ImageJ v 1.47, Rasband, W.S., U.S. National Institute of Health, Bethesda, Maryland, USA).

\section{SEM sample preparation and microscopy}

The remaining halves of fixed apical segments were prepared for SEM using the same procedure as above through dehydration in $100 \%$ ethanol. The dehydrated samples were then dried using hexamethyldisilazane

Table 1: Collection site locations (latitude, longitude) and descriptions and taxonomic authorities of the six Halimeda species examined.

\begin{tabular}{|c|c|c|}
\hline Collection site description & Species & Taxonomic authority \\
\hline \multicolumn{3}{|c|}{ (A) Back Reef Lagoon $\left(19^{\circ} 41^{\prime} 46^{\prime \prime} \mathrm{N}, 80^{\circ} 03^{\prime} 39^{\prime \prime} \mathrm{W}\right)$} \\
\hline (i) Sandy bottom & H. incrassata & (Ellis) Lamouroux \\
\hline \multicolumn{3}{|l|}{$<2$ m deep } \\
\hline \multicolumn{3}{|l|}{$1300 \mu \mathrm{mol}$ photons $\mathrm{m}^{-2} \mathrm{~s}^{-1}$} \\
\hline \multicolumn{3}{|c|}{ (B) Spur and Groove Fore Reef $\left(19^{\circ} 42^{\prime} 3^{\prime \prime} \mathrm{N}, 80^{\circ} 03^{\prime} 25^{\prime \prime} \mathrm{W}\right)$} \\
\hline (i) Sandy bottom & H. monile & (Ellis et Solander) Lamouroux \\
\hline \multicolumn{3}{|l|}{$15 \mathrm{~m}$ deep } \\
\hline \multicolumn{3}{|l|}{$635 \mu \mathrm{mol}$ photons $\mathrm{m}^{-2} \mathrm{~s}^{-1}$} \\
\hline (ii) Hard bottom & H. tuna & (Ellis et Solander) Lamouroux \\
\hline \multicolumn{3}{|l|}{$12 \mathrm{~m}$ deep } \\
\hline \multicolumn{3}{|l|}{$760 \mu \mathrm{mol}$ photons $\mathrm{m}^{-2} \mathrm{~s}^{-1}$} \\
\hline \multicolumn{3}{|c|}{ (C) Outer Fore Reef Ledge $\left(19^{\circ} 42^{\prime} 9^{\prime \prime} \mathrm{N}, 80^{\circ} 03^{\prime} 25^{\prime \prime} \mathrm{W}\right)$} \\
\hline (i) Rocky overhang & H. copiosa & Goreau et Graham \\
\hline $18 \mathrm{~m}$ deep & H. goreauii & Taylor \\
\hline \multicolumn{3}{|l|}{$50 \mu \mathrm{mol}$ photons $\mathrm{m}^{-2} \mathrm{~s}^{-1}$} \\
\hline (ii) Hard bottom & H. opuntia & (Linnaeus) Lamouroux \\
\hline \multicolumn{3}{|l|}{$18 \mathrm{~m}$ deep } \\
\hline $570 \mu \mathrm{mol}$ photons $\mathrm{m}^{-2} \mathrm{~s}^{-1}$ & & \\
\hline
\end{tabular}

Site descriptions include substratum, water depth and irradiance taken at time of specimen collection. 
H. copiosa

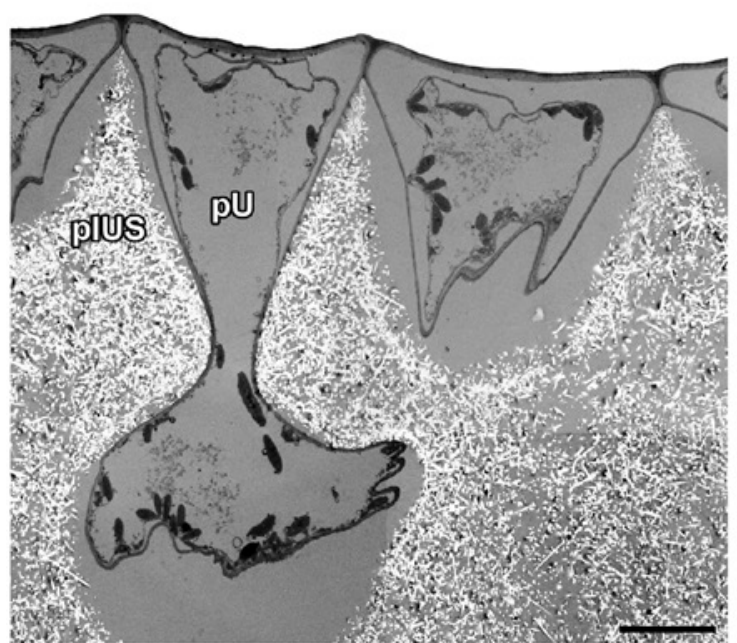

H. opuntia

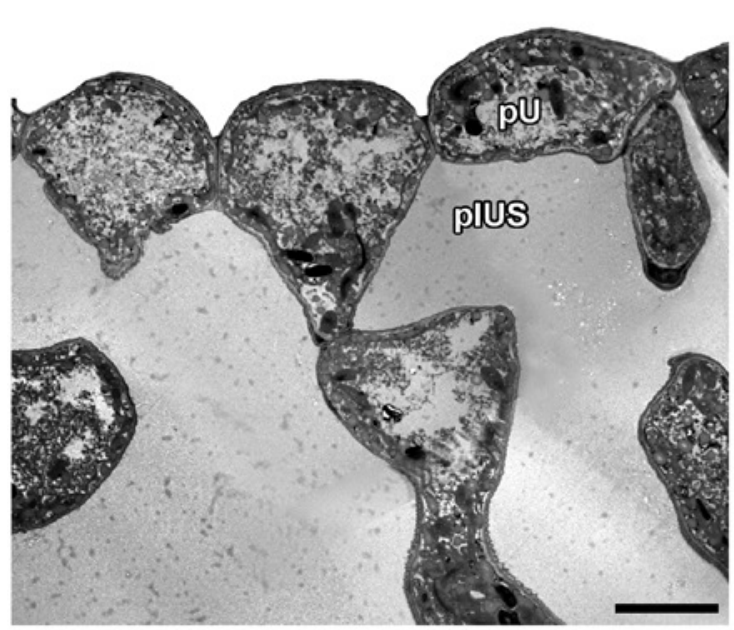

H. tuna

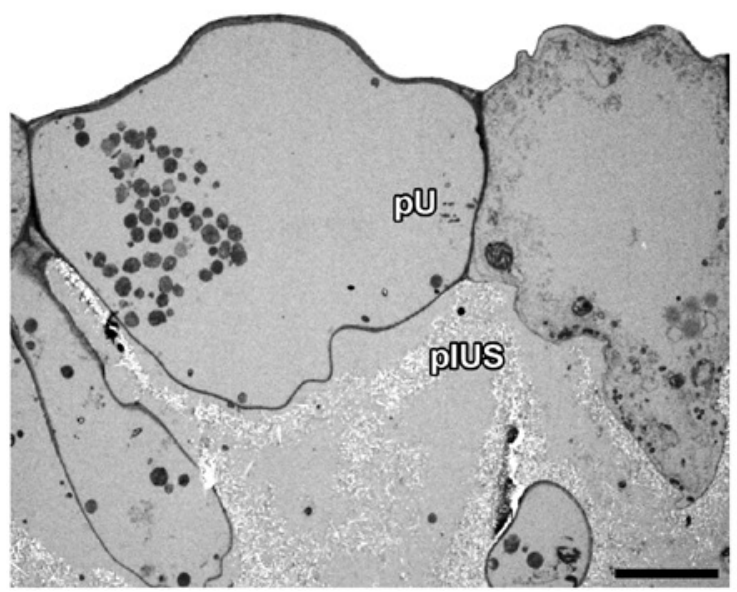

H. goreauii

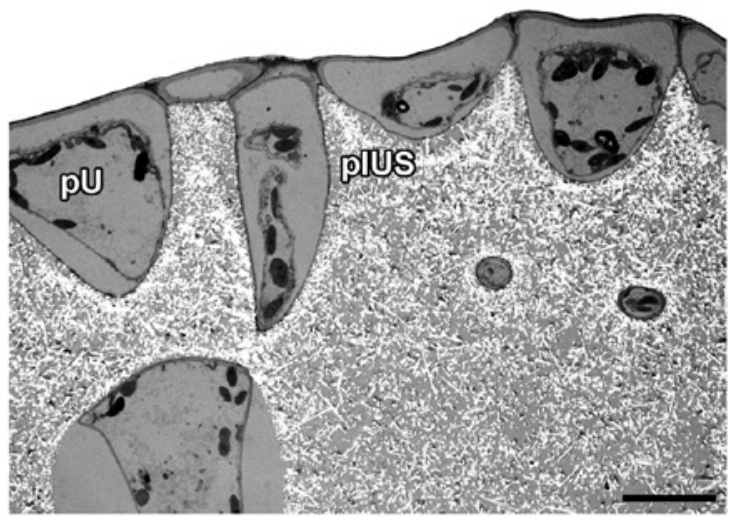

H. monile

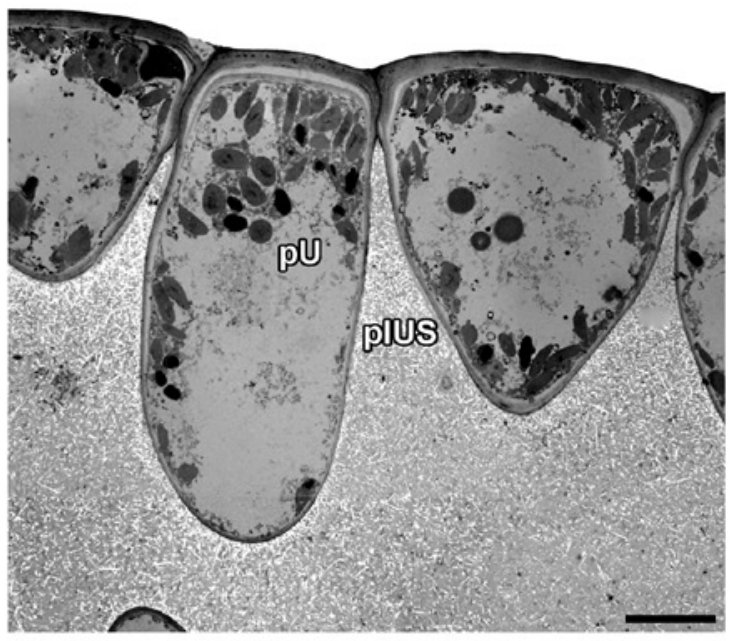

H. incrassata

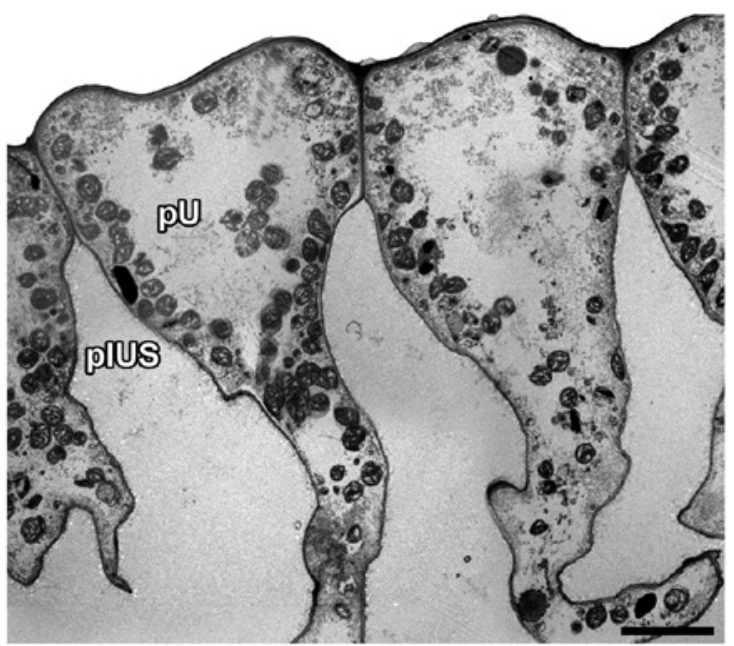

Figure 4: Examples of transmission electron microscope images from which surface diameters of primary utricles (pU) were determined from six Halimeda species collected on reefs from Little Cayman Island.

Note aragonite crystals in the primary inter-utricle spaces (pIUS). Scale bar $=10 \mu \mathrm{m}$. 
(HMDS; Electron Microscopy Sciences, Hatfield, PA, USA). Dried samples were fractured vertically on the midplane to expose interior surfaces and mounted on aluminum stubs using carbon adhesive tabs. Stub-mounted samples were sputter coated with palladium and viewed with an SEM (FEI XL 30 Field Emission ESEM/SEM, Thermo Fisher Scientific, Inc., Hillsboro, OR, USA).

\section{Tissue mineral content}

Tissue mineral content (assumed to be primarily $\mathrm{CaCO}_{3}$ ) was determined for aboveground portions of whole thalli. Fresh aboveground tissues were rinsed in distilled water to remove salts, dried at $60^{\circ} \mathrm{C}$ to constant weight and acidified (95:5\% of DI: $12 \mathrm{~N} \mathrm{HCl} \mathrm{vol:vol)} \mathrm{until} \mathrm{no} \mathrm{effer-}$ vescence formed following acid addition. Post-acidified samples were rinsed with distilled water, dried at $60^{\circ} \mathrm{C}$ and weighed. The differences in pre-acidified and postacidified weights were assumed to be the mineral proportion of the thalli tissue and reported as $\% \mathrm{CaCO}_{3}$.

\section{Statistical analyses}

Calcium carbonate content data were log transformed to meet assumptions of normality (Shapiro-Wilk's test) and homogeneity of variance (Levene's test), and compared among species using an ANOVA followed by a priori contrasts (SAS University Edition, SAS Institute Inc., Cary, NC, USA). Linear regression analyses were used to determine relationships between average primary utricle size, diffusion pathway length, and $\mathrm{CaCO}_{3}$ content across the species (SigmaPlot 11.0, Systat Software Inc., San Jose, CA, USA). All statistical analyses were considered significant at $p<0.01$. Measurements of primary utricle surface diameters and diffusive pathway lengths within individual samples were not independent and violated the assumptions of ANOVA. Therefore, individual sample means were compared to evaluate similarities and differences across the six species examined for these measurements.

\section{Results}

\section{Primary utricle size}

The average sizes of primary utricles determined by surface diameters differed among the single representative samples of the six species examined (Table 2, Figure 4). Halimeda tuna and $H$. goreauii had the largest and smallest primary utricles with average surface diameters of $\sim 41$ and $19 \mu \mathrm{m}$, respectively. Halimeda incrassata and $H$. monile primary utricle surface diameters were intermediate between those of $H$. tuna and $H$. goreauii, ranging from $\sim 31$ to $32 \mu \mathrm{m}$. Halimeda copiosa and H. opuntia also had similar primary utricle surface diameters averaging $\sim 26$ and $24 \mu \mathrm{m}$, respectively, and were on the low end of the range for the species examined.

\section{Diffusion pathway length}

Diffusion pathway lengths measured as adhesion length of adjacent primary utricles also varied by species (Figure 5, Table 2). The longest diffusion pathway observed was $\sim 19 \mu \mathrm{m}$ in Halimeda tuna. Halimeda incrassata and $H$. monile also had relatively long diffusion pathways of $\sim 10-13 \mu \mathrm{m}$. The shortest diffusion pathways up to $\sim 6 \mu \mathrm{m}$ in length were similar in $H$. copiosa, $H$. goreauii, and $H$. opuntia. We also found a positive linear relationship between average diffusion pathway length and primary utricle surface diameter across the examined species (Figure 6A).

Table 2: Primary utricle size, diffusion pathway length, and thalli mineral content for six Halimeda species collected on Little Cayman Island reefs.

\begin{tabular}{lrrr}
\hline Species & Primary utricle diameter $(\mu \mathrm{m})$ & Diffusion pathway length $(\mu \mathrm{m})$ & Tissue mineral content $^{\dagger}\left(\% \mathrm{CaCO}_{3}\right)$ \\
\hline H. copiosa & $26.2 \pm 7.0$ & $4.2 \pm 2.9$ & $95 \pm 1.2^{\mathrm{a}}$ \\
H. goreauii & $19.3 \pm 6.5$ & $3.2 \pm 1.0$ & $95 \pm 2.3^{\mathrm{a}}$ \\
H. incrassata & $32.9 \pm 6.7$ & $13.1 \pm 2.0$ & $79 \pm 9.7^{\mathrm{b}}$ \\
H. monile & $32.1 \pm 6.3$ & $9.7 \pm 2.0$ & $90 \pm 1.8^{\mathrm{c}}$ \\
H. opuntia & $24.4 \pm 5.0$ & $5.6 \pm 1.8$ & $86 \pm 3.4^{\mathrm{c}}$ \\
H. tuna & $40.6 \pm 7.3$ & $18.9 \pm 7.6$ & $72 \pm 6.8^{\mathrm{b}}$ \\
\hline
\end{tabular}

Reported values are means $( \pm S D)$ of measurements for primary utricle diameter $(n=11-17)$ and diffusion pathway length $(n=7-14)$ taken in one sample replicate for each species, and replicate thalli $(n=10)$ for tissue mineral content.

tSignificant differences $(\mathrm{p}<0.01)$ among species based on a priori contrasts of log transformed data are indicated with different superscript letters. 
H. copiosa

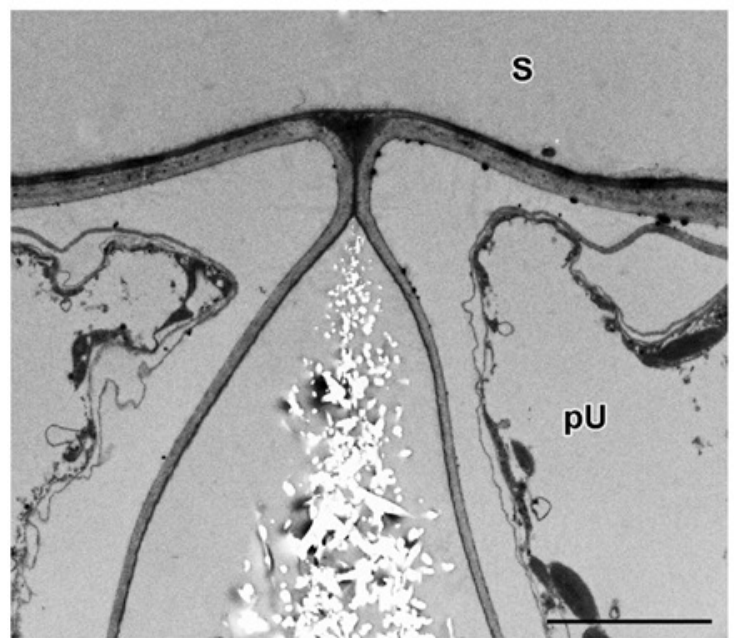

H. opuntia

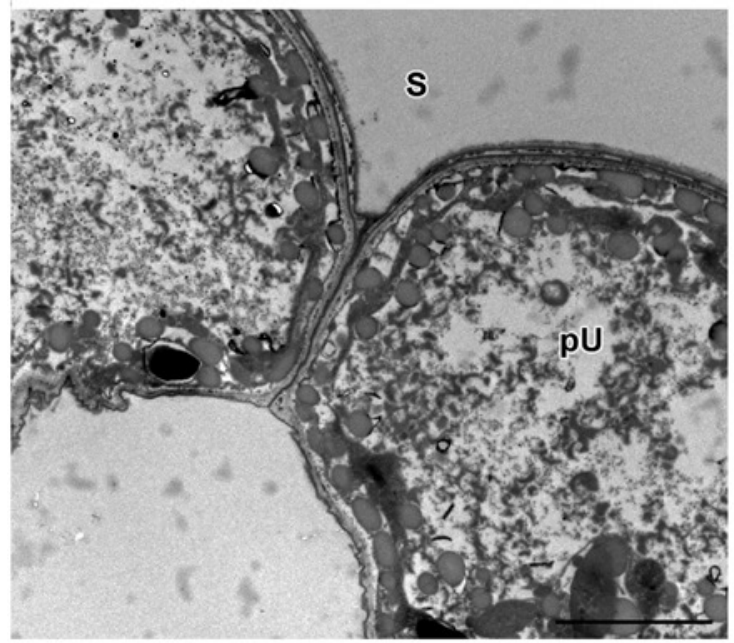

\section{H. tuna}

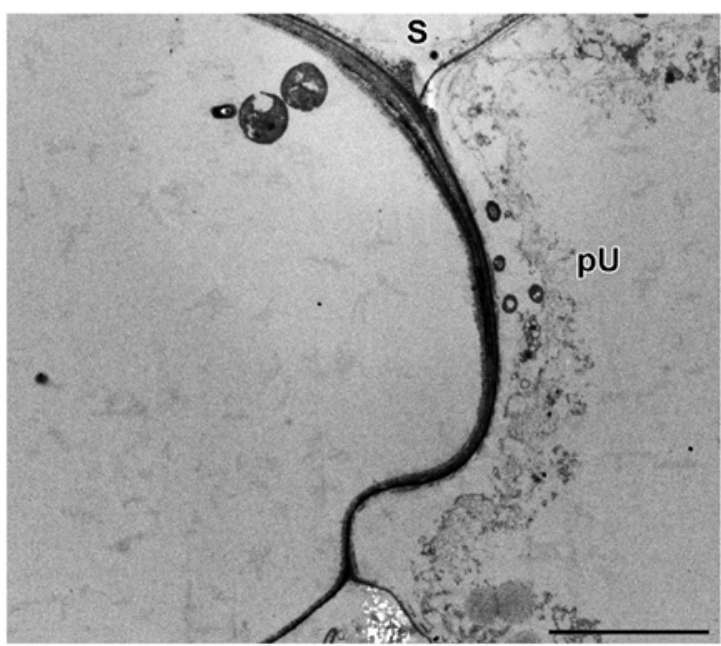

H. goreauii

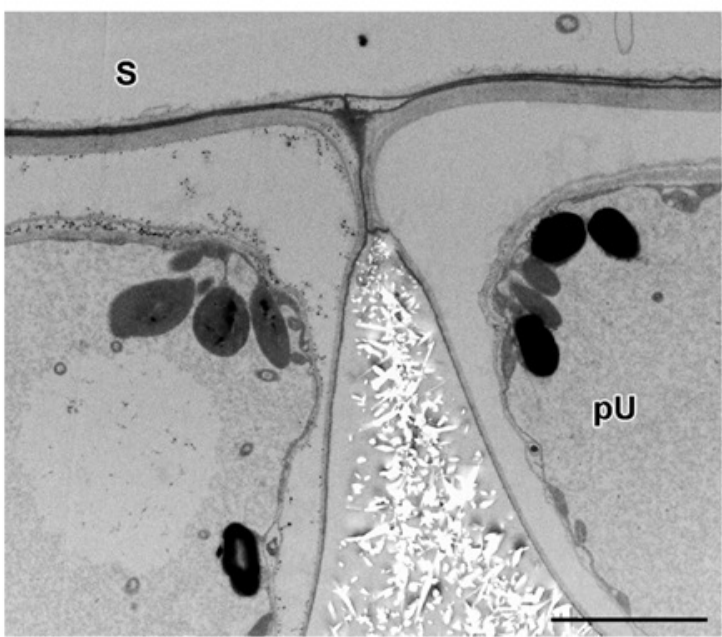

H. monile

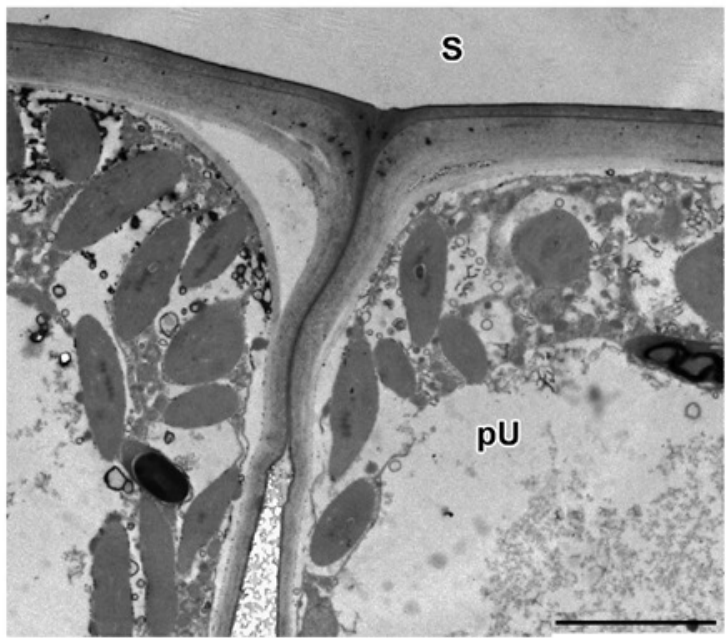

H. incrassata

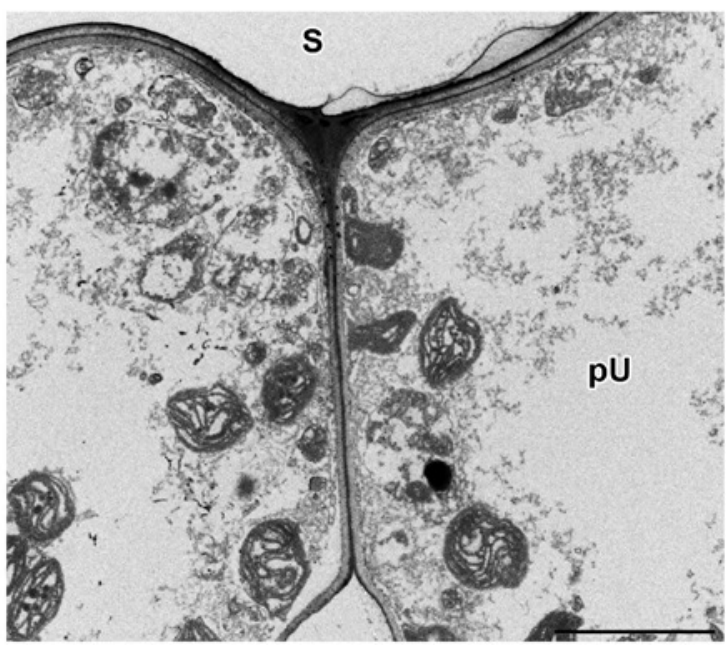

Figure 5: Examples of transmission electron microscope images from which adhesion length between adjacent primary utricles (pU), defined as diffusion pathway length, were determined from six Halimeda species collected on reefs from Little Cayman Island.

The diffusion pathway can be seen to physically isolate the primary inter-utricle space (pIUS) from external seawater (S). Scale bar $=10 \mu \mathrm{m}$. 

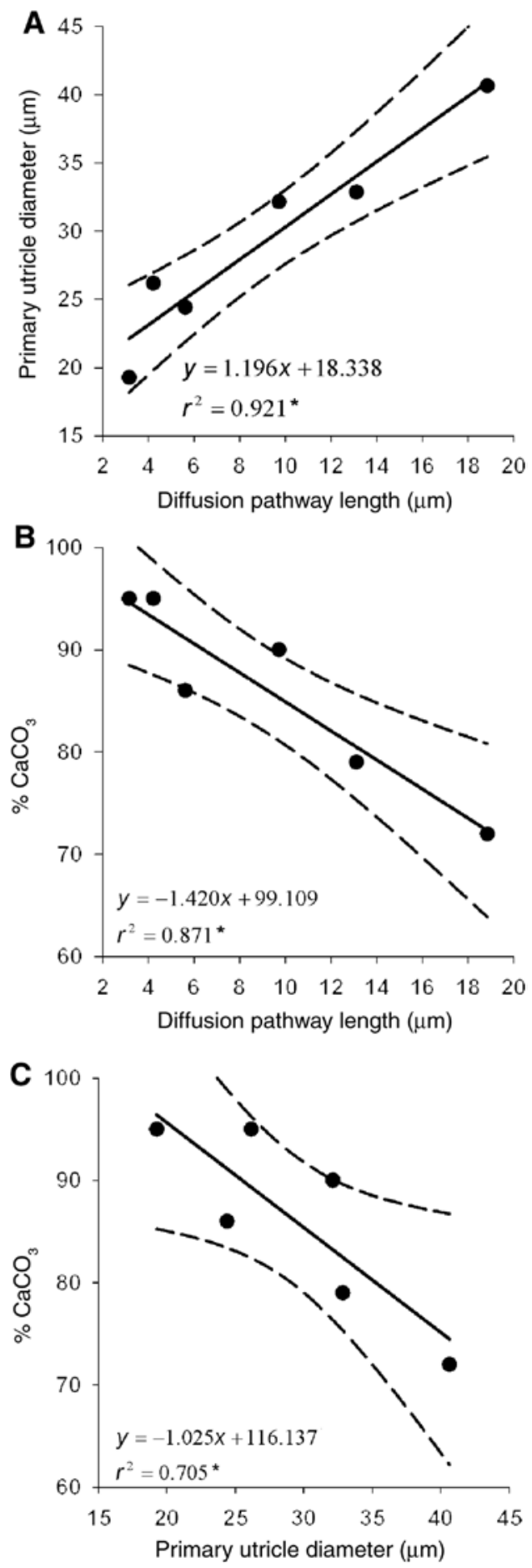

Figure 6: Linear relationships between $(A)$ average diffusion pathway length and surface diameter of primary utricles in one representative sample, (B) average diffusion pathway length and tissue mineral content $\left(\% \mathrm{CaCO}_{3}\right)$ in whole thalli $(\mathrm{n}=10)$ and $(\mathrm{C})$ average primary utricle diameter and tissue mineral content $\left(\% \mathrm{CaCO}_{3}\right)$ of six Halimeda species collected from Little Cayman Island.

Standard deviations of the average values are reported in Table 2. Solid lines represent the linear regression best fit and dashed lines indicate the $95 \%$ confidence limit of the regression. Asterisks indicate that the regression coefficients are significant $(p<0.05)$.

\section{Tissue mineral content}

Mineral content $\left(\% \mathrm{CaCO}_{3}\right)$ of above-ground tissue for whole thalli significantly differed among the examined species $\left(\mathrm{F}_{5,59}=54.2, \mathrm{p}<0.01\right)$, and statistically distinct groups were identified (Table 2). The highest average $\mathrm{CaCO}_{3}$ content (95\%) was found in Halimeda copiosa and $H$. goreauii. Calcium carbonate content was 5\%-9\% lower, on average, in $H$. monile and $H$. opuntia than in $H$. copiosa and $H$. goreauii. Halimeda incrassata and $H$. tuna were the least calcified species with average $\mathrm{CaCO}_{3}$ contents of 79 and $72 \%$, respectively. Linear regression analyses between average $\mathrm{CaCO}_{3}$ content compared to diffusion pathway length for all species revealed a strong inverse relationship (Figure 6B). There was also a strong inverse relationship between average $\mathrm{CaCO}_{3}$ content and primary utricle surface diameter (Figure 6C).

\section{Aragonite crystal microstructure}

Apical segment SEM analyses revealed both similarities and differences in the aragonite crystal microstructure of the primary inter-utricle spaces of the six species examined (Figure 7). Each species' primary inter-utricle space was densely filled with aragonite crystals predominantly in the form of aragonite needles up to $5 \mu \mathrm{m}$ in length and $0.1-0.5 \mu \mathrm{m}$ in width. In the primary inter-utricle spaces of Halimeda incrassata and H. tuna, the dominant crystals were slender needles not exceeding $0.2 \mu \mathrm{m}$ in width. For $H$. copiosa and $H$. goreauii, needles ranged from 0.2 to $0.4 \mu \mathrm{m}$ in width in the primary inter-utricle space interior and at the boundary where primary utricle filaments retracted from the primary inter-utricle space leaving an imprint in the crystals. A similar observation of dense needle $(0.2-0.3 \mu \mathrm{m}$ in width) infill in the interior and boundary of the primary interutricle space was also observed for H. opuntia. In H. monile, needles $0.2 \mu \mathrm{m}$ in width, on average, also populated the primary inter-utricle space interior, but these were not the dominant crystal form observed at the primary inter-utricle space boundary. Rather than needles, a thick (4-12 $\mu \mathrm{m})$ rim of micron-sized $(<1 \mu \mathrm{m})$ anhedral crystals was observed adjacent to the primary utricles in $H$. monile. Although the other species examined did not form a dense rim of microanhedral crystals, small crystal aggregates could be seen on top of short needles in the vicinity of the primary utricle. In some cases, these small crystal aggregates were prominent where the diffusion pathway enters the primary interutricle space (Figure 7).

Micro-anhedral crystal aggregates were observed where the diffusion pathway between adhered primary 
H. copiosa

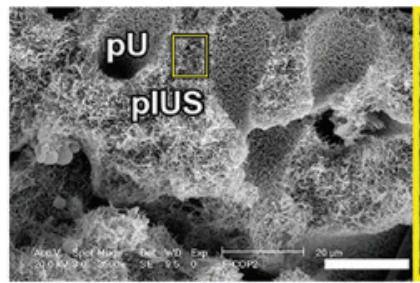

H. opuntia

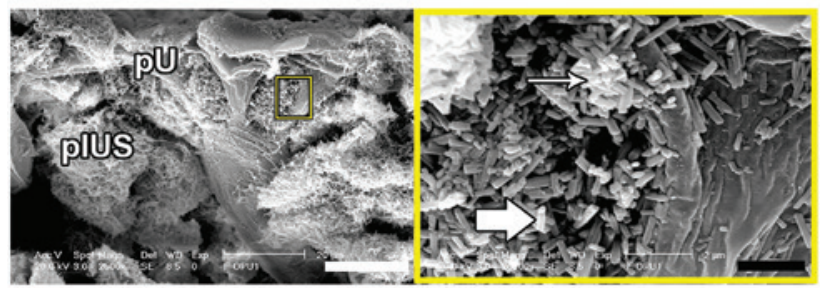

H. incrassata

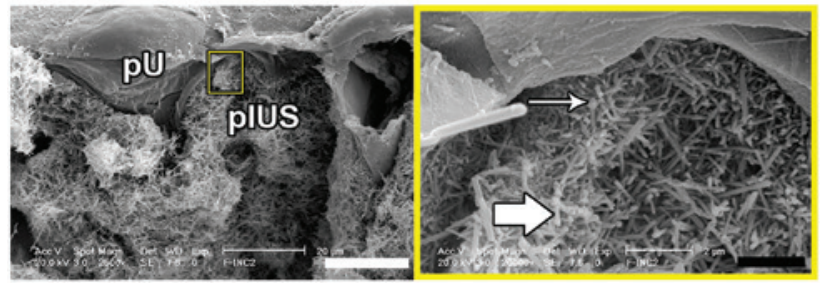

H. goreauii
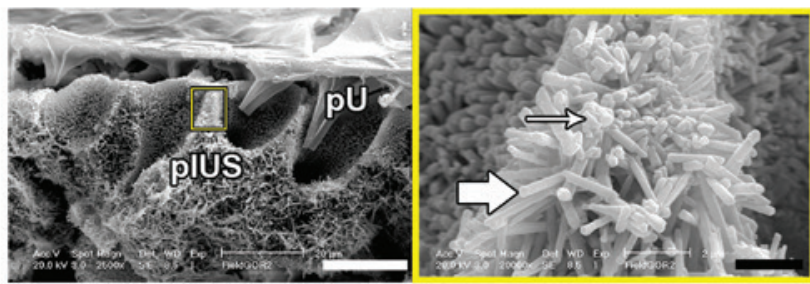

H. monile
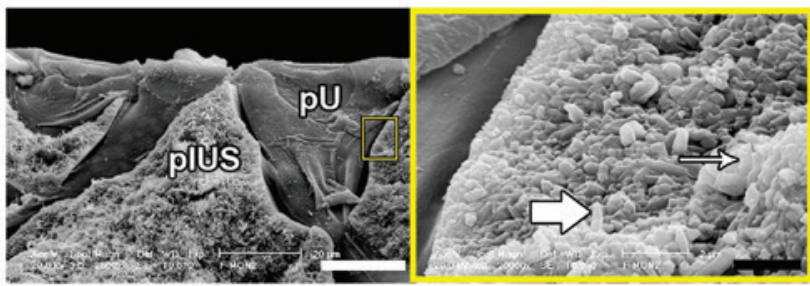

H. tuna

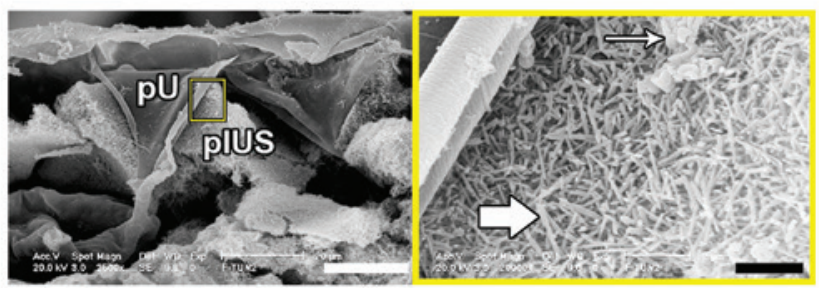

Figure 7: Aragonite crystal microstructure of the six Halimeda species examined.

Images (with white scale bars $=20 \mu \mathrm{m}$ ) show the locations of primary utricles $(\mathrm{pU})$ and primary inter-utricle spaces (pIUS). Higher magnification images (with black scale bars $=2 \mu \mathrm{m}$ ) of the $\mathrm{pU}$ - pIUS boundary show species' diversity in widths of short $(<5 \mu \mathrm{m})$ aragonite needles (large arrows) and abundance and locations of small $(<1 \mu \mathrm{m})$ anhedral crystals (small arrows).

utricles is adjacent to the primary inter-utricle space, primarily in species (H. copiosa, H. goreauii, H. opuntia) with the smallest primary utricles $(<27 \mu \mathrm{m}$ diameter $)$ and shortest diffusive path lengths $(<6 \mu \mathrm{m})$. In contrast, micro-anhedral crystal aggregates were less apparent where the diffusive pathway joins the primary inter-utricle space in species (H. incrassata, H. tuna) with the widest primary utricles ( $>32 \mu \mathrm{m}$ ) and longest diffusive pathways $(>13 \mu \mathrm{m})$. Halimeda monile was the exception, with complete micro-anhedral crystal infill in the primary interutricle space even though its morphology was comparable to H. incrassata.

\section{Discussion}

There was an inverse relationship between tissue mineral content and diffusion pathway length $\left(\mathrm{r}^{2}=0.87\right.$; Figure $\left.6 \mathrm{~B}\right)$ that was potentially influenced by primary utricle size $\left(r^{2}=0.70\right.$; Figure 6C) since size and pathway length were highly correlated $\left(\mathrm{r}^{2}=0.92\right.$; Figure $\left.6 \mathrm{~A}\right)$ in the six Halimeda species examined. These results imply that primary utricle size and/or diffusion pathway length may influence the degree of calcification within the Halimeda genus. For example, average $\mathrm{CaCO}_{3}$ content was $95 \%$ in $\mathrm{H}$. copiosa and $H$. goreauii, species with 4.5 to 6 -fold shorter diffusion pathways compared to $\mathrm{H}$. tuna $\left(72 \% \mathrm{CaCO}_{3}\right)$. Shorter diffusion pathways may lower diffusive resistance for the influx of $\mathrm{Ca}^{2+}$ and potentially $\mathrm{HCO}_{3}{ }^{-}$or $\mathrm{CO}_{3}{ }^{2-}$ from seawater to the primary inter-utricle space, increasing the potential for $\mathrm{CaCO}_{3}$ formation (Borowitzka and Larkum 1976). Higher $\mathrm{CaCO}_{3}$ content in species with shorter pathways could also promote greater efflux of $\mathrm{H}^{+}$, a by-product of calcification whose build-up in the calcifying region inhibits $\mathrm{CaCO}_{3}$ formation and/or promotes dissolution (Jokiel 2011, 2013, Ries 2011, Cyronak et al. 2015).

Diffusive ion transport associated with the primary inter-utricle space, and subsequent localized changes in $\left[\mathrm{H}^{+}\right]$and $\left[\mathrm{CO}_{3}{ }^{2-}\right]$ may have contributed to the different densities and locations of micro-anhedral crystals among the six Halimeda species examined. The occurrence of microanhedral crystals primarily in Halimeda species with short diffusive pathways (H. copiosa, H. goreauii, H. opuntia), as 
well as higher $\mathrm{CaCO}_{3}$ content in this study, suggests that greater exchange with external seawater may positively affect calcification, but also alter the primary inter-utricle space aragonite needle crystal form.

In contrast to Halimeda species with short diffusive pathways, those with long pathways $(H$. incrassata, $H$. tuna) were dominated by slender needles and lacked micro-anhedral crystal aggregates. A long path length for diffusion would isolate the primary interutricle space from the external seawater and limit cellular metabolism effects, although this interaction and its effect on calcification is presently unclear. The low $\mathrm{CaCO}_{3}$ content associated with long diffusion path lengths found in the present study may be attributable to reduced crystal formation, perhaps limited by $\mathrm{Ca}^{2+}$ and/ or inorganic carbon availability. Alternatively, greater build-up of $\mathrm{H}^{+}$and $\mathrm{CO}_{2}$ in the primary inter-utricle space from calcification and cellular respiratory processes, respectively, may have contributed to greater dissolution of aragonite needles leading to more narrow forms. Aragonite needles in $H$. opuntia and $H$. tuna have been shown to narrow in response to elevated partial pressure of $\mathrm{CO}_{2}\left(\mathrm{CO}_{2}\right)$ (Robbins et al. 2009, Wizemann et al. 2015). Narrow needles in new segments grown in $\mathrm{CO}_{2}$-enriched (>650 $\mu \mathrm{atm}$ ) seawater were suggested to be formed under rapid calcification, potentially catalyzed by an increase in external carbonic anhydrase activity at low $\mathrm{pH}$ (Hofmann et al. 2014, Wizemann et al. 2015). Although a few studies observed thinner needles, in our previous work on seven Halimeda species we found no changes in crystal morphology under year $2100(\sim 1000 \mu \mathrm{atm})$ compared to ambient $p \mathrm{CO}_{2}$ levels (Peach et al. 2016, 2017).

The relationships among primary utricle morphology, degree of calcification and crystal forms among the six Halimeda species examined corresponded to evolutionary lineages. For example, species of the Opuntia lineage (H. copiosa, H. goreauii, and H. opuntia) exhibited more slender primary utricles, shorter diffusion pathways and higher $\mathrm{CaCO}_{3}$ content in comparison to species belonging to the Halimeda (H. tuna) and Rhipsalis (H. incrassata and $H$. monile) lineages (Hillis 2001). These morphological lineage characteristics are likely the result of longterm evolutionary adaptations to abiotic (e.g. irradiance, wave energy) and biotic (e.g. grazing pressure) conditions at natural growth sites (Hillis-Colinvaux 1980, Kooistra et al. 2002, Verbruggen and Kooistra 2004). Increased pliability and reduced drag in some species (e.g. H. tuna and $\mathrm{H}$. incrassata) with low $\mathrm{CaCO}_{3}$ content and swollen utricles may have allowed this evolutionary lineage to become established primarily in shallow back reef and lagoon sites (Kooistra et al. 2002). In contrast, high tissue
$\mathrm{CaCO}_{3}$ content in $H$. goreauii and $H$. copiosa may be an adaptation to reduce herbivorous fish grazing in structurally complex habitats such as the reef ledge where these species were collected (Hay et al. 1983, Paul and Hay 1986, Kooistra et al. 2002).

In conclusion, inter-species' differences in primary utricle morphology accounted for variability in mineral content and aragonite crystal forms in six Halimeda species. The characteristics generally corresponded to the evolutionary lineages (Halimeda, Opuntia, Rhipsalis) to which they belong. Halimeda copiosa, H. goreauii, and H. opuntia (Opuntia lineage) had small primary utricles and short diffusion pathways leading to the primary inter-utricle spaces, where aggregates of micro-anhedral crystals were observed on top of needles (0.2-0.4 $\mu \mathrm{m}$ in width). This was in contrast to the minimal micro-anhedral formations and more narrow $(0.1-0.2 \mu \mathrm{m})$ needles observed in H. tuna (Halimeda lineage) and $H$. incrassata (Rhipsalis lineage), species with larger primary utricles and longer diffusion pathways. Although morphologically similar to $H$. incrassata, primary inter-utricle spaces in $H$. monile were heavily cemented with micro-anhedral crystals and aragonite needles were virtually absent. The present study revealed ultra- and micro-structural distinctions among species that have been suggested to cause mixed responses of Halimeda species to OA (Price et al. 2011, Comeau et al. 2013, Campbell et al. 2014, 2015, Meyer et al.2015). Species of the Opuntia lineage have been shown in several multi-species investigations to be more susceptible to OA relative to species of other lineages, including Halimeda and Rhipsalis. For example, Price et al. (2011) found that $H$. opuntia (Opuntia lineage) exhibited a more negative calcification response to elevated $p \mathrm{CO}_{2}$ when compared to $H$. taenicola, a less calcified species of the Halimeda lineage with larger utricles. Campbell et al. $(2014,2015)$ also found that exposure to elevated $p \mathrm{CO}_{2}$ led to significant reductions in net calcification for $\mathrm{H}$. opuntia, in contrast to $H$. incrassata, a less calcified species of the Rhipsalis lineage whose net calcification rates were unaffected. Based on these experimental results, we hypothesize that weakly calcified species with large primary utricles and long diffusion pathways, and therefore species with smaller and more isolated inter-utricle spaces, may be more tolerant to long-term acidified seawater exposure. Further microscopy work on additional samples is needed to verify our findings, and may also assist in clarifying the role of morphology in OA tolerance for the Halimeda genus over the long-term.

Acknowledgements: Funding for SEM and TEM work was provided by a Dissertation Year Award (K.E.P.) and Climate Change Initiative Grant (M.S.K.) awarded by Florida 
Atlantic University. We thank the Cayman Islands Marine Conservation Board and Department of Environment for permitting collection and exportation of specimens, and are grateful to Carrie Manfrino and the Little Cayman Research Centre staff for logistic support on Little Cayman Island. We also thank Elizabeth Dutra for her assistance with field collections and Chris Johnson for his assistance with figures.

\section{References}

Böhm, L., D. Fütterer and E. Kaminski. 1978. Algal calcification in some Codiaceae (Chlorophyta): ultrastructure and location of skeletal deposits. J. Phycol. 14: 486-493.

Borowitzka, M.A. and A.W.D. Larkum. 1976. Calcification in the green alga Halimeda. III. The sources of inorganic carbon for photosynthesis and calcification and a model of the mechanism of calcification. J. Exp. Bot. 27: 879-893.

Campbell, J.E., J.D. Craft, N. Muehllehner, C. Langdon and V.J. Paul. 2014. Responses of calcifying algae (Halimeda spp.) to ocean acidification: implications for herbivores. Mar. Ecol. Prog. Ser. 514: 43-56.

Campbell, J.E., J. Fisch, C. Langdon and V.J. Paul. 2015. Increased temperature mitigates the effects of ocean acidification in calcified green algae (Halimeda spp.). Coral Reefs 35: 357-368.

Comeau, S., P.J. Edmunds, N.B. Spindel and R.C. Carpenter. 2013. The responses of eight coral reef calcifiers to increasing partial pressure of $\mathrm{CO}_{2}$ do not exhibit a tipping point. Limnol. Oceanogr. 58: 388-398.

Cyronak, T., K.G. Schulz and P.L. Jokiel. 2015. The Omega myth: what really drives lower calcification rates in an acidifying ocean. ICES J. Mar. Sci. 73: 558-562.

Hay, M.E., T. Colburn, and D. Downing. 1983. Spatial and temporal patterns in herbivory on a Caribbean fringing reef: the effects on plant distribution. Oecologia 58: 299-308.

Hillis. L.W. 2001. The calcareous reef alga Halimeda (Chlorophyta, Bryopsidales): a cretaceous genus that diversified in the cenozoic. Palaeogeogr. Palaeoclimatol. Palaeoecol. 166: 89-100.

Hillis-Colinvaux, L.W. 1980. Ecology and taxonomy of Halimeda: Primary producer of coral reefs. Adv. Mar. Biol. 17: 1-327.

Hofmann, L.C., J. Heiden, K. Bischof and M. Teichberg. 2014. Nutrient availability affects the response of the calcifying chlorophyte Halimeda opuntia (L.) J.V. Lamouroux to low pH. Planta 239: 231-242.

Jokiel, P.L. 2011. Ocean acidification and control of reef coral calcification by boundary layer limitation of proton flux. Bull. Mar. Sci. 87: 639-657.

Jokiel, P.L. 2013. Coral reef calcification: carbonate, bicarbonate and proton flux under conditions of increasing ocean acidification. Proc. R. Soc. B 280: 20130031.

Littler, D.S. and M.M. Littler. 2000. Caribbean Reef Plants. Offshore Graphics Inc., Washington, D.C. 542 pp.

Kooistra, W.H.C.F., E.G.G. Coppejans and C. Payri. 2002. Molecular systematics, historical ecology, and phylogeography of Halimeda (Bryopsidales). Mol. Phylogenet. Evol. 24: 121-138.
Meyer, F.W., N. Vogel, M. Teichberg, S. Uthicke and C. Wild. 2015. The physiological response of two green calcifying algae from the Great Barrier Reef towards high dissolved inorganic and organic carbon (DIC and DOC) availability. PLoS One 10: e0133596.

Paul, V. and M. Hay. 1986. Seaweed susceptibility to herbivory: chemical and morphological correlates. Mar. Ecol. Prog. Ser. 33: 255-264.

Peach, K.E., M.S. Koch and P.L. Blackwelder. 2016. Effects of elevated $p \mathrm{CO}_{2}$ and irradiance on growth, photosynthesis and calcification in Halimeda discoidea. Mar. Ecol. Prog. Ser. 544: 143-158.

Peach, K.E., M.S. Koch, P.L. Blackwelder and C. Manfrino. 2017. Calcification and photophysiology response to elevated $p \mathrm{CO}_{2}$ in six Halimeda species from contrasting irradiance environments on Little Cayman Island reefs. J. Exp. Mar. Biol. Ecol. 486: 114-126.

Price, N.N., S.L. Hamilton, J.S. Tootell and J.E. Smith. 2011. Speciesspecific consequences of ocean acidification for the calcareous tropical green algae Halimeda. Mar. Ecol. Prog. Ser. 440: 67-78.

Ries, J.B. 2011. A physicochemical framework for interpreting the biological calcification response to $\mathrm{CO}_{2}$-induced ocean acidification. Geochim. Cosmochim. Acta 75: 4053-4064.

Robbins, L.L., P.O. Knorr and P. Hallock. 2009. Response of Halimeda to ocean acidification: field and laboratory evidence. Biogeosciences Discuss. 6: 4895-4918.

Verbruggen, H. and W.H. Kooistra. 2004. Morphological characterization of lineages within the calcified tropical seaweed genus Halimeda (Bryopsidales, Chlorophyta). Eur. J. Phycol. 39: 213-228.

Wizemann, A., F.W. Meyer, L.C. Hofmann, C. Wild and H. Westphal. 2015. Ocean acidification alters the calcareous microstructure of the green macro-alga Halimeda opuntia. Coral Reefs 34: 941-954.

\section{Bionotes}

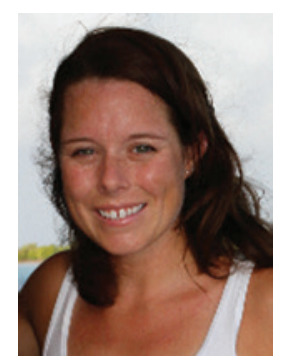

Katherine E. Peach

Biological Sciences Department, Aquatic Plant Ecology Lab, Florida Atlantic University, 777 Glades Rd, Boca Raton, FL 33431, USA; and Science and Wellness Department, Broward College South Campus, 7200 Pines Blvd, Pembroke Pines, FL 33024, USA, peach.kate@comcast.net

Katherine E. Peach is an Assistant Professor of Biology at Broward College in Pembroke Pines, Florida, USA. She earned her PhD in Integrative Biology in May 2016 from Florida Atlantic University, an MS in Oceanography at Nova Southeastern University, and dual BS degrees in Marine Science and Biology from Coastal Carolina University. Her research interests include determining whether dominant reef macroalgae and corals have the capacity to acclimate and adapt to future changes in environmental conditions, with an emphasis on ocean acidification. 


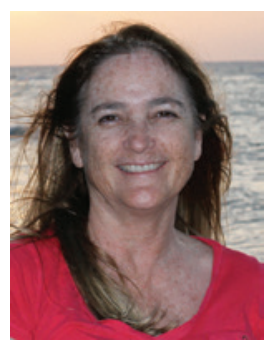

\section{Marguerite S. Koch}

Biological Sciences Department, Aquatic Plant Ecology Lab, Florida Atlantic University, 777 Glades Rd, Boca Raton, FL 33431, USA

Marguerite S. Koch is a Professor in the Biological Sciences Department of Florida Atlantic University. She received her PhD in Marine Biology and Fisheries from the University of Miami, an MS in Marine Science from Louisiana State University, and a BS in Biology from Tulane University. She studied coral reef ecology at Fairleigh Dickinson University, fisheries and estuarine ecology at the University of Washington, and was a graduate exchange scholar investigating nutrient cycling in coastal marine ecosystems at the University of Exeter. Her present research examines biogeochemical changes in tropical marine ecosystems and ecophysiological responses of marine plants under climate change.

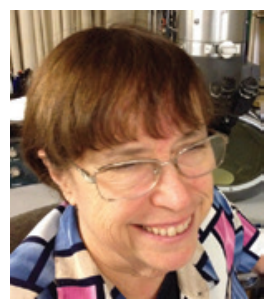

\section{Patricia L. Blackwelder}

University of Miami, Center for Advanced Microscopy, 1252 Memorial Drive, Coral Gables, FL 33146, USA; and Nova Southeastern University, 8000 North Ocean Drive, Dania Beach, FL 33004, USA

Patricia L. Blackwelder is an Associate Professor at Nova Southeastern University and Supervisor of the University of Miami Center for Advanced Microscopy (UMCAM). Dr. Blackwelder received her PhD in 1976 at the University of South Carolina, Columbia SC, USA. Her research focuses on the application of electron microscopy to ultrastructure/biomineralization in marine invertebrate organisms and biomedical studies. She has been co-author on 55 publications in these fields.

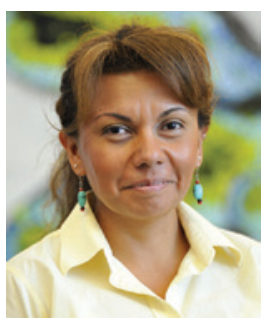

Debbie Guerrero-Given

Max Planck Florida Institute for

Neuroscience, Electron Microscopy Facility, One Max Planck Way, Jupiter, FL 33458, USA

Debbie Guerrero-Given is a research scientist in the Electron Microscopy (EM) Facility at the Max Planck Florida Institute for Neuroscience. She enjoys the morphological analysis of the variety of samples that are brought in the EM facility and every challenge to produce high quality images that relate to the different functions of the brain.

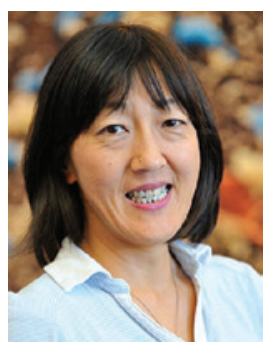

Naomi Kamasawa

Max Planck Florida Institute for Neuroscience, Electron Microscopy Facility, One Max Planck Way, Jupiter, FL 33458, USA

Naomi Kamasawa heads the Electron Microscopy (EM) Facility in the Max Planck Florida Institute for Neuroscience. She has long-term experience in electron microscopy studying different kinds of biological specimens including bacteria, yeasts, plants, cultured cells, nervous tissues from invertebrates and vertebrates using various EM techniques and applications. She is very enthusiastic about visualizing high-resolution morphology in order to understand their physiological function. 